EUGENIUSZ SOBOL

\title{
PUSZKIN ANDRZEJA TURCZYŃSKIEGO
}

Istotną cechą książki Andrzeja Turczyńskiego „Ten szalony Pan Puszkin. Słowo o udręce"1 jest duży szacunek jej autora do rosyjskiej kultury - to szczególnie ważne w naszym wieku pełnym antagonizmów, roszczeń historycznych i rewanżyzmów. Wydawałoby się, że Turczyński nie ma powodów, by kochać Rosję. W roku 1940 został wywieziony z matką i siostrą z rodzinnego Turczynówka na Podolu do Kazachstanu, a do Polski powrócił dopiero w roku 1948. A jednak nurt duchowości bizantyjsko-rosyjskiej przenika cały jego dorobek pisarski. Wystarczy spojrzeć tylko na tytuły niektórych jego książek: zbioru opowiadań Dietdomszczyzna, tomu esejów Święto ikony, cyklu powieści Tryptyk ruski i Latopis. Innym, ważnym składnikiem twórczości Turczyńskiego sa jego książki poświęcone życiu i twórczości Jarosława Iwaszkiewicza - Ząb madrości i Pan Bóg, pisarz i diabeł.

Napisanie biografii Puszkina w dzisiejszych czasach jest dużym wyzwaniem. Badacz ma do czynienia z dwoma, nawzajem się wykluczającymi strategiami interpretacyjnymi życia rosyjskiego poety, z których każda ma swoje mocne uzasadnienie w faktach. Z jednej strony jest to Puszkin - liberał i wolnomyśliciel, którego świadomość określały idee oświeceniowe i powstanie dekabrystów. Z drugiej - nadworny poeta cara Mikołaja I, sławiący w wierszach potęgę samodzierżawia i odmawiający podbitym przez Rosję narodom prawa do

1 Andrzej Turczyński, Ten szalony Pan Puszkin. Stowo o udręce, Wydawnictwo Prószyński i S-ka, Warszawa 2008. 
wolności. Oczywiście, należy podkreślić, że ta pierwsza interpretacja przez dziesięciolecia była oficjalnym stanowiskiem radzieckiego literaturoznawstwa. Dwoistość Puszkina bardzo wyraźnie przejawiła się w jego stosunku do Polski. Poeta przyjaźnił się z Adamem Mickiewiczem i okazywał szczery podziw dla geniuszu polskiego wieszcza, tłumaczył jego poezję. A potem napisał tak antypolskie wiersze, jak Oszczercom Rosji i Na rocznicę Borodina, które zbulwersowały nawet postępową rosyjską inteligencję. Więc gdzież tu szukać owego „tajnego płomienia wolności", o którym w bardzo przejmujący sposób pisał Aleksander Błok w jednym ze swych ostatnich wierszy Do Domu Puszkinowskiego w 1921 r.: „Пушкин! Тайную свободу/Пели мы вослед тебе!/Дай нам руку в непогоду/Помоги в немой борьбе!"2.

Głównym celem, który przyświecał Turczyńskiemu przy napisaniu tej książki, była bez wątpienia próba odbrązowienia postaci rosyjskiego poety. To zadanie zostało zrealizowane na tyle skutecznie, że autor często zostawia czytelnika sam na sam ze sprzecznościami tkwiącymi w charakterze Puszkina i unika odpowiedzi na pytanie, czy w jego ocenie życie rosyjskiego poety było życiem zmarnowanym czy też szczęśliwym. Turczyński pisze wprost: „Puszkin Niezłomny, Puszkin Wcielenie Męstwa i Prawdy - to postać fantastyczna, stworzona z imaginacji jego bezkrytycznych wielbicieli, niewiele ma wspólnego z prawdziwym Puszkinem"3. W innym miejscu niemal otwarcie przyznaje się do powinowactwa z tekstem Andrzeja Siniawskiego Przechadzki z Puszkinem, którego autor ,zderzył carsko-bolszewicką imperialną baśń z rzeczywistością, oczyszczając poetę z bielidła i pozłotki wieków: bóstwo stało się w niej człowiekiem"4. Chociaż szukając inspiracji dla Turczyńskiego, wcale nie trzeba, moim zdaniem, sięgać zbyt daleko - jedną z najważniejszych będzie dramat Maskarada Jarosława Iwaszkiewicza. Utwór ten Turczyński, jako wnikliwy

2 A. Błok, Puszkinskomu Domu, w: Sobranije soczinienij w wos'mi tomach, Moskwa-Leningrad 1960, t. 3, s. 376. Przekład M. Jastruna: „Wolność zabronioną! - w odach/Wysławialiśmy jak w dni twe,/Rękę nam Puszkinie podaj/Pomóż w burzy w niemej bitwie”. (A. Błok, Do Domu Puszkinowskiego, przeł. M. Jastrun, w: Poezje, wybór S. Pollak, Kraków 1981, s. 373).

A. Turczyński, Ten szalony Pan Puszkin. Stowo o udręce. Warszawa 2008, s. 161.

4 Tamże, s. 84. 
badacz twórczości mistrza ze Stawiska, przyswoił sobie bardzo dokładnie.

Podstawową metafora, przy której pomocy autor próbuje uchwycić skomplikowany układ relacji wokół Aleksandra Siergiejewicza, będzie klatka. Należy zaznaczyć, że w polskiej puszkinologii takie pojęcie już było wcześniej obecne, znajdziemy je chociażby w monografii Wiktora Woroszylskiego Kto zabit Puszkina ${ }^{5}$. W dyskursie postmodernistycznym motyw wykluczenia i alienacji jednostki ze społeczeństwa jest obecnie bardzo popularny. W tym sensie wyobcowanie Puszkina jawi się w sposób wielokrotny: jako artysty, potomka Murzyna, osoby podejrzanej politycznie, nie mogącej swobodnie podróżować. Ale dla autora biografii najważniejsze jest przedstawienie konfliktu zbuntowanej jednostki, poety romantycznego z thumem i pospólstwem. Tę drugą stronę, paradoksalnie, reprezentuje cesarz Mikołaj I. Poprzez wprowadzenie poprawek cenzuralnych chciał niejako współuczestniczyć w powstawaniu dzieł Puszkina, żeby w zwierciadle genialnej twórczości swego najwybitniejszego poety Rosja i jej car wyglądały jak najlepiej. Narzędziem badawczym Turczyńskiego jest przede wszystkim analiza psychologiczna. Na podstawie dokumentów historycznych, wspomnień bliskich mu osób i donosów agentów carskiej ochranki autor podejmuje próbę rekonstrukcji portretu psychologicznego wielkiego artysty - zadania, wydawałoby się, niewykonalnego. Ale Turczyński jest też literatem. Puszkin w jego biografii został przedstawiony jako ekscentryk, ogarnięty przez lęki i obsesje, erotoman, nałogowy gracz karciany, nie stroniący od alkoholu. Wierzył w przesądy i wróżby, na przykład w przepowiednię Cyganki, że poniesie śmierć z rąk wysokiego blondyna. Właśnie tak wyglądał d'Anthès, od kuli którego zginął w pojedynku. Dużą uwagę autor przywiązuje do pozornie nic nie znaczących szczegółów: jak się ubierał Puszkin, gdzie bywał, jak spędzał wolny czas. Ale właśnie na postawie tych informacji usiłuje zrozumieć psychikę artysty.

Prefigurację owej klatki, skomplikowanej sieci międzyludzkich relacji, która uczyniła życie poety na tyle nieznośnym, że nawet sam pragnął i szukał śmierci, Turczyński znajduje w urazach dziecinnych

Tamże, s. 84. 
młodego Aleksandra. Jego rodzice zostali przedstawieni jako azjatyccy despoci. Pojęcie klatki można uznać kluczowym dla tej książki. Na początku klatką jest cała Rosja - kraj z którego Aleksander Siergiejewicz bezskutecznie stara się wyrwać, by odetchnąć ,świeżym powietrzem" Europy. Potem zostaje zawężona do miejsc, do których został zesłany przez cesarza Aleksandra I - Kiszyniowa, Odessy i majątku w Michajłowskim. Nowy władca Mikołaj I, który objął tron w 1825 r., zamiast bezpośredniej represji zastosował wobec Puszkina bardziej wyrafinowaną i perfidną politykę. Posłuchał rady naczelnego żandarma imperium hr. Benkendorfa, który przekonywał, że pióro Puszkina należy odpowiednio skierować. Wtedy tą klatką stał się Petersburg, a poeta tkwił w niej, znajdując się w sieci rozmaitych zależności od władzy, wśród których najważniejsza, zdaniem Turczyńskiego, była zależność finansowa. Autor Eugeniusza Oniegina lubił wystawny tryb życia, z dumą mówił, że stać go na najdroższy obiad za 14 rubli. W jednym z rozdziałów książki znajdziemy dokładnie odtworzoną buchalterię rodziny Puszkina. Pomimo, że wydawcy płacili mu ,po czerwońcu za linijkę", jego długi przekraczały 60 tysięcy rubli, część z których pokrył skarb państwa. „Najjaśniejszy Pan (...) stworzył mi możliwość przyzwoitego życia z mojej pracy"6 - stwierdzał poeta. Ta klatka miała złote pręty. Woliera, w której miotał się rosyjski geniusz niczym kanarek, coraz bardziej się zawężała, aż w końcu poczuł się osaczony przez bliskich. Turczyński nie rozwiązał podstawowej zagadki życia Puszkina - czy intryga, która doprowadziła do feralnego pojedynku z d'Anthèsem, była zainspirowana przez Mikołaja I zakochanego w pięknej Natalii Puszkin. Iwaszkiewicz w dramacie Maskarada nie zawahał się natomiast opisać intymnych schadzek żony Puszkina z carem, ale pisarz ze Stawiska mógł sobie pozwolić na puszczenie wodzy wyobraźni. Warto zauważyć, że Turczyński także nie stroni od wprowadzania elementów literackich do swoich rozważań. Jego tekst eseistyczno-prozatorski, w którym przedstawił Puszkina na łożu śmierci, wyróżnia się pisarskim kunsztem. s. 297.

${ }^{6}$ List A. Puszkina do A. Benkendorfa z 16 kwietnia 1830, cyt. za A. Turczyński, dz. cyt., 
Za zdarzenie przełomowe w życiu Puszkina, kiedy wyparł się on dekabrystów i został pochlebcą tronu, autor biografii uznał rozmowę poety z carem Mikołajem I, jaka odbyła się we wrześniu 1826 r. Poeta jechał na nią pełen najgorszych przeczuć. Obawiał się, że z Petersburga zostanie zesłany wprost na syberyjską katorgę. Był to jeden z najgorszych okresów w życiu poety. Wielu aresztowanych uczestników powstania grudniowego z 1825 r. w trakcie śledztwa zeznawało, że posiadali odpisy jego wierszy, z których czerpali inspirację dla wolnościowych poglądów. Przeciwko Puszkinowi toczyło się osobne dochodzenie o ustalenie autorstwa wiersza $\mathrm{Na} 14$ grudnia oraz poematu Gabrieliada. Turczyński podważa wykreowaną przez radzieckich badaczy legendę o tym, że Puszkin podczas rozmowy z carem w żadnym wypadku nie odstapił od buntowniczych poglądów, co więcej, z dumą oświadczył, że na pewno przyłączyłby do powstańców, gdyby był wtedy w Petersburgu? ${ }^{7}$. Jedno jest pewne, pisze autor biografii, po owej pamiętnej rozmowie Puszkin rozpoczął niebezpieczny flirt z monarchą, który skończył się dla niego tak tragicznie. Badacz, eksponując zagadnienie relacji między artystą a władzą, podążył tropem innego, bliskiego sobie polskiego puszkinisty, mam tutaj na uwadze Jarosława Iwaszkiewicza, autora dramatu Maskarada i eseju Puszkin, zamieszczonego w zbiorze Petersburg.

Nie można stwierdzić z całą pewnością, że wizerunek Puszkina, z którym mamy do czynienia w biografii, został ukształtowany wyłącznie pod wpływem utworów Iwaszkiewicza. Obaj pisarze obficie czerpali ze wspólnych źródeł, mając do wyboru wiele ciekawych opracowań. Sposób, w jaki Iwaszkiewicz i Turczyński dokonywali interpretacji dzieł swoich poprzedników, można prześledzić na przykładzie postaci Natalii, żony Puszkina. Badacze zazwyczaj opisują ją przy pomocy kategorii femme fatal. Jej chłodną apolińską urodę przeciwstawiają dionizyjskiemu i żywiołowemu usposobieniu poety. Iwaszkiewicz skwapliwie podchwytuje ten wątek, zwłaszcza że był

W podobny sposób przedstawił relacje między władcą a poetą Iwaszkiewicz w Maskaradzie. Niczym Kordian z Bogiem, Puszkin stacza walkę z carem o „rząd dusz”. „Cesarz: (...) Zrozumiałeś, co to jest Rosja! Puszkin: Nie nie... tego nikt nie rozumie! Cesarz: że Rosja - to ja! Puszkin: Nie! Nie, tak nie jest. Równie dobrze mógłbym o sobie powiedzieć, że Rosja - to ja”. (J. Iwaszkiewicz, Maskarada, w: Dzieła, Dramaty. Warszawa 1980, s. 271). 
on zbieżny z panującymi w literaturze dwudziestolecia międzywojennego tendencjami mizoginistycznymi. Awantury między żoną a mężem wybuchają w dramacie jedna po drugiej. Puszkin daje upust swej anormalnej podejrzliwości: „Ubóstwiam cię, kocham cię! Tylko nie

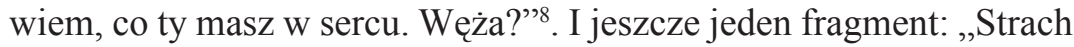
mnie ogarnia. Nic tak nie ukrywa ludzkiej myśli, jak piękne ciało. (...) Kto to jest? Kim ona jest? Ta piękna obca bogini. Zeszła z Olimpu na ziemię. Persefona wracająca z piekieł. Kto ty jesteś?"9. Za niezwykle trafny należy uznać pomysł autora w zakresie indywidualizacji języka bohatera. Puszkin w tym fragmencie wyraża uczucia przy pomocy sztafażu mitologicznego, bardzo mocno zakorzenionego w jego własnej poezji. Porównanie Natalii do Persefony też nie jest przypadkowe. Wydaje się, że postać bohaterki greckiego mitu i jej związek z motywem kobiety fatalnej bardzo zainteresowały autora dramatu. Wkrótce po opublikowaniu w 1939 r. Maskarady napisał opowiadanie Powrót Prozerpiny, wydane już po wojnie w zbiorze Nowele włoskie. Natalia Puszkin, Persefona (Prozerpina), Kora Leeds, bohaterka tego utworu - takie zestawienie kobiet fatalnych w twórczości Iwaszkiewicza pokazuje, jak rozległą świadomość kulturową posiadał ten pisarz, swobodnie poruszający się pomiędzy odległymi epokami literackimi. Turczyński zaś każdą legendę związaną z Puszkinem i jego otoczeniem traktuje podejrzliwie, skrupulatnie tropi rozmaite przekłamania i przerysowania, które powstawały na użytek ideologii. Ze smutkiem stwierdza, że chyba już nigdy nie poznamy całej prawdy o małżeństwie Puszkina, bo listy Natalii do jej męża bezpowrotnie zaginęły, prawdopodobnie zostały zniszczone przez bolszewików, bo zawierały informacje sprzeczne $z$ forsowanym przez nich wizerunkiem poety. Turczyński przyznaje, że kobiety miały zgubny wpływ na Puszkina, a za główną twórczynię negatywnego portretu Natalii uznał Marinę Cwietajewą. Gorąca wielbicielka poezji autora Jeźdźca Miedzianego żywiła, zdaniem autora monografii, szczerą niechęć do tej kobiety, w której widziała wyimaginowaną rywalkę do serca rosyjskiego ge-

8 Tamże, s. 219.

9 Tamże, s. 232. 
niusza $^{10}$. To jeszcze raz potwierdza, że dla badacza najważniejsza okazuje się subiektywna motywacja psychologiczna ludzkich czynów i słów.

Pewnym mankamentem książki są zbyt arbitralne stwierdzenia jej autora, które nie znajdują potwierdzenia w ówczesnej sytuacji społeczno-politycznej. Tak na przykład Turczyński pisze, że Puszkin „bywał szowinistycznym nacjonalista, $\mathrm{w}$ gruncie rzeczy pogardzał demokracją i odrzucał ją w imię wielkomocarstwowej rosyjskiej idei hegemonistycznej" ${ }^{11}$. Wydaje się, że autor zbyt mechanicznie zinterpretował poglądy Puszkina przez pryzmat realiów współczesności. Warto zaznaczyć, że na początku XIX wieku większość państw europejskich niewiele miała wspólnego z ustrojem demokratycznym. Oczywiście, w kwestii wolności jednostki Rosja znajdowała się na szarym końcu, wielką hańbą tego kraju była obecność klasy chłopów pańszczyźnianych. „W Berlinie też poetów do ciupy sadzają” - ironicznie mówi cesarz w Maskaradzie ${ }^{12}$.

Książka została wydana w wydawnictwie Prószyński i S-ka i jest obliczona na popularyzację wiedzy o Puszkinie. Znajdziemy w niej bardzo wnikliwą analizę tekstów ogólnie już znanych. Są to opublikowane jeszcze w Polsce Ludowej wybór materiałów Wieriesajewa Puszkin żywy oraz praca zbiorowa Puszkin we wspomnieniach wspótczesnych, a także dzienniki i listy. Zatem należy podkreślić duże walory bibliograficzne książki Turczyńskiego.

W tym roku uroczyście obchodzimy dwudziestą rocznicę upadku komunizmu w Polsce. Porównujemy też nasze dwudziestolecie $\mathrm{z}$ dwudziestoleciem międzywojennym. W obu przypadkach można zauważyć, że Polacy wtedy zdobywają się na autentyczne zainteresowanie rosyjską literatura, gdy przestaje ona być instrumentem zniewolenia i ucisku politycznego, jak to miało miejsce w czasie zaborów czy reżimu komunistycznego. W polemice z nią kształtują się postawy polskich intelektualistów i pisarzy, a twórczość Andrzeja Turczyńskiego jest tego przykładem. I nieprzypadkowo ten proces zaczyna

\footnotetext{
10 A. Turczyński, dz. cyt., s. 432.

11 Tamże, s. 119.

12 J. Iwaszkiewicz, dz. cyt.s.256.
} 
się właśnie od odczytywania na nowo rosyjskiego wieszcza Aleksandra Puszkina. Tom przekładów Juliana Tuwima Lutnia Puszkina był uznawany za jedno z najważniejszych wydarzeń literackich tamtego okresu, podobnie jak prace o Puszkinie autorstwa wybitnego rusycysty Wacława Lednickiego. 